\title{
Proteasome Inhibitors and Their Pharmacokinetics, Pharmacodynamics, and Metabolism
}

\author{
Jinhai Wang *, Ying Fang, R. Andrea Fan and Christopher J. Kirk \\ Kezar Life Sciences, South San Francisco, CA 94080, USA; yfang@kezarbio.com (Y.F.); \\ afan@kezarbio.com (R.A.F.); ckirk@kezarbio.com (C.J.K.) \\ * Correspondence: jwang@kezarbio.com
}

Citation: Wang, J.; Fang, Y.; Fan, R.A.; Kirk, C.J. Proteasome Inhibitors and Their Pharmacokinetics,

Pharmacodynamics, and Metabolism. Int. J. Mol. Sci. 2021, 22, 11595.

https://doi.org/10.3390/

ijms222111595

Academic Editor:

Christophe Morisseau

Received: 27 September 2021

Accepted: 22 October 2021

Published: 27 October 2021

Publisher's Note: MDPI stays neutral with regard to jurisdictional claims in published maps and institutional affiliations.

Copyright: (C) 2021 by the authors. Licensee MDPI, Basel, Switzerland. This article is an open access article distributed under the terms and conditions of the Creative Commons Attribution (CC BY) license (https:/ / creativecommons.org/licenses/by/ $4.0 /)$.

\begin{abstract}
The proteasome is responsible for mediating intracellular protein degradation and regulating cellular function with impact on tumor and immune effector cell biology. The proteasome is found predominantly in two forms, the constitutive proteasome and the immunoproteasome. It has been validated as a therapeutic drug target through regulatory approval with 2 distinct chemical classes of small molecular inhibitors (boronic acid derivatives and peptide epoxyketones), including 3 compounds, bortezomib (VELCADE), carfilzomib (KYPROLIS), and ixazomib (NINLARO), for use in the treatment of the plasma cell neoplasm, multiple myeloma. Additionally, a selective inhibitor of immunoproteasome (KZR-616) is being developed for the treatment of autoimmune diseases. Here, we compare and contrast the pharmacokinetics (PK), pharmacodynamics (PD), and metabolism of these 2 classes of compounds in preclinical models and clinical studies. The distinct metabolism of peptide epoxyketones, which is primarily mediated by microsomal epoxide hydrolase, is highlighted and postulated as a favorable property for the development of this class of compound in chronic conditions.
\end{abstract}

Keywords: proteasome; proteasome inhibitors; immunoproteasome; immunoproteasome inhibitors; epoxide hydrolases; microsomal epoxide hydrolase

\section{Introduction}

The ubiquitin/proteasome system constitutes one of the primary means by which intracellular proteins are degraded. Ubiquitin/proteasome-regulated pathways contribute to the dynamic control of key cell signaling components and the maintenance of overall cellular homeostasis, as well as are associated with multiple pathological conditions, including cancer, autoimmune disorders, and neurodegenerative diseases [1-6]. The 26S proteasome contains a multi-catalytic enzyme complex mediating protein degradation, the $20 \mathrm{~S}$ core, which is found predominantly in 2 forms. The constitutive proteasome is expressed ubiquitously throughout the body and is responsible for protein degradation in tissues, including heart, kidney, and liver. In the constitutive proteasome, proteolytic activities are encoded in the $\beta 5, \beta 1$, and $\beta 2$ subunits [7-9]. The immunoproteasome is expressed mostly in immune cells and contains low molecular mass polypeptide (LMP 7, LMP2), and multi-catalytic endopeptidase complex-like 1 (MECL-1) instead of $\beta 5, \beta 1$, and $\beta 2$, respectively, as catalytic subunits (Figure 1). Inhibition of both types of proteasome results in antitumor activity via induction of apoptosis, while selective inhibition of the immunoproteasome results in cytokine blockade in vitro and anti-inflammatory activities in in vivo models [10-13].

Dual proteasome inhibition has been clinically validated through regulatory approval of 3 compounds, all with equipotency for $\beta 5$ and LMP7, for use in the treatment of B-cell neoplasms, such as multiple myeloma and mantle cell lymphoma [14-17]. These compounds comprise 2 distinct chemical classes: the reversible boronic acid derivatives, bortezomib (VELCADE ${ }^{\circledR}$ ) and ixazomib (NINLARO ${ }^{\circledR}$ ), and the irreversible covalent tetrapeptide epoxyketone-based compound, carfilzomib (KYPROLIS ${ }^{\circledR}$ ). These three proteasome 
inhibitors (PIs) are currently approved for the treatment of multiple myeloma (MM) or mantle-cell lymphoma (MCL) [18,19]. Another epoxyketone-based inhibitor, KZR-616, which selectively targets the immunoproteasome, is currently being evaluated in Phase 2 clinical trials in patients with autoimmune disorders, including Lupus Nephritis (LN), Dermatomyositis (DM), and Polymyositis (PM) (Figure 2, Table 1) [20].

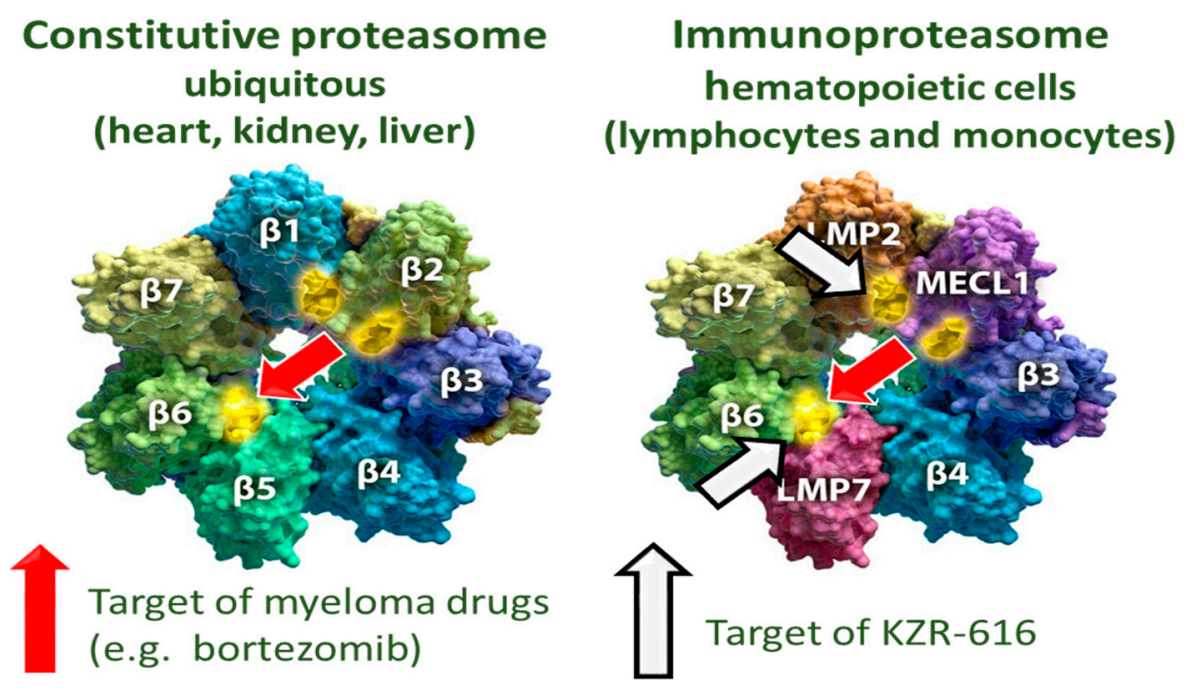

Figure 1. Proteasome subunit composition.<smiles>CC(C)C[C@H](NC(=O)[C@H](Cc1ccccc1)NC(=O)c1cnccn1)B(O)O</smiles>

Bortezomib (dual proteasome inhibitor)<smiles>CC(C)C[C@H](NC(=O)CNC(=O)c1cc(Cl)ccc1Cl)B(O)O</smiles>

Ixazomib (dual proteasome inhibitor)<smiles>COC[C@H](NC(=O)c1cnc(C)s1)C(=O)N[C@@H](COC)C(=O)N[C@@H](Cc1ccccc1)C(=O)C1(C2CO2)CO1</smiles>

Oprozomib (dual proteasome inhibitor)<smiles>CC(C)C[C@H](NC(=O)[C@H](CCc1ccccc1)NC(=O)CN1CCOCC1)C(=O)N[C@@H](Cc1ccccc1)C(=O)N[C@@H](CC(C)C)C(=O)[C@]1(C)CO1</smiles>

Carfilzomib (dual proteasome inhibitor)<smiles>COc1ccc(C(O)[C@H](NC(=O)[C@H](C)NC(=O)CN2CCOCC2)C(CC2=CCCC2)C(=O)C2(C)CO2)cc1</smiles>

KZR-616 (Immunoproteasome inhibitor)

Figure 2. Proteasome inhibitors approved and in clinical trials. 
Table 1. Properties of proteasome inhibitors and their clinical use.

\begin{tabular}{|c|c|c|c|c|c|c|c|c|}
\hline $\begin{array}{l}\text { Proteasome } \\
\text { Inhibitors }\end{array}$ & Warhead & Class & Targets & Administration & Absorption & Clearance & $\begin{array}{l}\text { Subunit } \\
\text { Inhibition }\end{array}$ & $\begin{array}{l}\text { Metabolic } \\
\text { Pathwas }\end{array}$ \\
\hline Bortezomib & Boronate & reversible & $\begin{array}{c}\text { Constitutive and } \\
\text { immunoproteasome }\end{array}$ & IV and SC & fast & fast & B5 and LMP7 & Hydrolases, CYPs \\
\hline Ixazomib & Boronate & reversible & $\begin{array}{c}\text { Constitutive and } \\
\text { immunoproteasome }\end{array}$ & IV and Oral & fast & fast & B5 and LMP7 & Hydrolases, CYPs \\
\hline Carfilzomib & Epoxyketone & Irreversible & $\begin{array}{l}\text { Constitutive and } \\
\text { immunoproteasome }\end{array}$ & IV & fast & fast & B5 and LMP7 & $\begin{array}{c}\text { Microsomal } \\
\text { epoxide hydrolase } \\
\text { peptidases, }\end{array}$ \\
\hline Oprozomib & Epoxyketone & Irreversible & $\begin{array}{l}\text { Constitutive and } \\
\text { immunoproteasome }\end{array}$ & Oral & fast & fast & B5 and LMP7 & $\begin{array}{c}\text { Microsomal } \\
\text { epoxide hydrolase } \\
\text { peptidases, CYPs }\end{array}$ \\
\hline KZR-616 & Epoxyketone & Irreversible & Immunoproteasome & SC & fast & fast & $\begin{array}{l}\text { LMP2 and } \\
\text { LMP7 }\end{array}$ & $\begin{array}{c}\text { Microsomal } \\
\text { epoxide hydrolase }\end{array}$ \\
\hline
\end{tabular}

Covalent drugs have traditionally been considered to be less favorable clinically due to the potential for off-target reactivity [21,22]. However, the success of the approved covalent inhibitors has led to a resurgence in the study and development of this class of small molecule agents. A covalent mechanism involves the irreversible binding of the inhibitor to the target resulting in potent inhibition in a biochemical, cellular, and in vivo setting. Two factors determine in vivo covalent occupancy: a physiologically relevant $\mathrm{k}_{\text {inact }} / \mathrm{K}_{\mathrm{i}}$ and an unbound AUC derived from a PK profile [23]. Boronic acid derivatives and epoxyketone-based proteasome inhibitors interact with the catalytic threonine residue within target catalytic subunits to exert their inhibitory activity. Boronic acid inhibitors form a slowly reversible tetrahedral intermediate between the boronate warhead of the molecule and the $\gamma-\mathrm{OH}$ side chain of the N-terminal threonine. In contrast, the mechanism of action of epoxyketone-based inhibitors involves nucleophilic attack of the $\gamma-\mathrm{OH}$ side chain of the N-terminal threonine residue on the epoxide carbonyl, followed by a second nucleophilic attack by the free $\alpha-\mathrm{NH}_{3}$ group of threonine on the epoxide ring, to form an irreversible, dual covalent adduct with the proteasome active site [24-26].

Dual proteasome inhibition is thought to mediate an anti-tumor response through direct induction of apoptosis. This is thought to occur via effects on multiple pathways, including blockade of the transcription factor NF-kB, alteration in productive cell cycle control, and the accumulation of unfolded and misfolded proteins, which trigger the unfolded protein response (UPR) [27]. Interestingly, selective inhibition of either the constitutive proteasome or the immunoproteasome in myeloma cells failed to induce apoptosis. In contrast to affecting cell survival, selective inhibition of the immunoproteasome with agents, such as KZR-616, mediate an anti-inflammatory response without affecting cell survival. The effects of immunoproteasome inhibition include reduced expression of cytokines from activated immune cells, blockade of Thelper 1 and 17 cell differentiation, and reduced fitness of plasma cells [28]. In mouse models of several autoimmune disorders, including rheumatoid arthritis and systemic lupus erythematous, KZR-616 blocked disease progression at well-tolerated doses without apparent signs of immunosuppression [29].

Atomic level molecular structures of proteasomes with 3 epoxyketone-based inhibitors, carfilzomib, oprozomib, and ONX 0914 (an immunoproteasome selective inhibitor), have been solved and reveal distinct binding features conveying insights on potency and selectivity [30]. Evidence from both x-ray crystallography and electron cyro-microscopy of the human constitutive $20 \mathrm{~S}$ proteasome with and without the dual inhibitors carfilzomib or oprozomib bound at resolutions as low as 1.9 angstroms indicates that the S3 binding pockets play a pivotal role in both agents selectivity for $\beta 5$ [26,31]. These studies also demonstrate 2 possible dual covalent interaction modes between the epoxyketone warhead with the catalytic $\mathrm{N}$-terminal threonine, a 1,4 morphiline, or 1,4 oxazapene adduct. Structural comparison with the mouse immunoproteasome and constitutive proteasome revealed differences at the $\mathrm{S} 1$ portion just proximal to the catalytic threonine within the chymotrypsin-like subunits [32]. In LMP7, the side chain of the methionine at position 45 
is stabilized by the aliphatic side chain of a conserved glutamine at position 53 , resulting in a larger S1 pocket than in $\beta 5$. The P1 phenylalanine of ONX 0914 is postulated to create steric hindrance in the smaller S1 pocket of $\beta 5$, thus reducing potency for this subunit relative to LMP7. Oprozomib, which also contains a P1 tyrosine, contains a methoxy group at the P3 position (versus alanine in ONX 0914), which is suitable for making van der Waals interactions with the hydrophobic S3 pocket of both chymotrypsin-like subunits, thereby explaining dual targeting nature of this compound [30]. KZR-616 has similar binding modes as ONX 014 with P1 cyclopentene replacing phenylalanine and an R-hydroxyl group substitution at the $\beta$ position of the P2 methyltyrosine side chain, resulting in hydrogen bonding with serine at position 21 [20].

While the structure, and function of the proteasome and the mechanisms of action of various proteasome inhibitors and their pharmacology has been reviewed extensively in the literature [33-36], there is no review on the metabolism of clinically applied proteasome inhibitors so far. In this review, we summarize the metabolism, pharmacokinetics, and pharmacodynamics of the three clinically-approved proteasome inhibitors and compare those profiles across chemical classes. Furthermore, we will discuss the unique features of metabolism of peptide epoxyketone-based proteasome inhibitors that potentially enable use of this chemical class in the treatment of chronic conditions.

\section{Pharmacokinetic, Pharmacodynamics, and Metabolism of Boronic Acid-Based Dual Proteasome Inhibitors}

Bortezomib, a dipeptide boronic acid derivative, was the first proteasome inhibitor to receive regulatory approval and is a mainstay in the treatment of multiple myeloma and other plasma cell malignancies [14]. Bortezomib is formulated as a mannitol ester and delivered to patients via intravenous (IV) or subcutaneous (SC) route, following one of two schedules of administrations consisting of 21-day cycles with dosing on Days 1, 4, 8 , and 11 or Days 1 and 8. Exposure was equivalent with both routes of administration at $1.3 \mathrm{mg} / \mathrm{m}^{2}$, and no differences in anti-tumor activity were noted between SC- and IVtreated patients [35]. Clearance of bortezomib is rapid in patients; however, accumulation is seen upon repeated dosing. As a single agent, bortezomib induced a dose-dependent inhibition of $20 \mathrm{~S}$ proteasome activity from $36 \%, 60 \%, 65 \%$, to $74 \%$, after 1-h treatment of at $0.40-, 1.04-, 1.20-$, and $1.38-\mathrm{mg} / \mathrm{m} 2$ doses, respectively [37]. Proteasome inhibition was also similar with both routes of administration. The mean maximum inhibition $\left(\mathrm{E}_{\max }\right)$ was 57 to $63.7 \%$ for SC, and approximately $69 \%$ for IV administration. Time to $\mathrm{E}_{\max }$ was longer (median of $120 \mathrm{~min}$ versus $5 \mathrm{~min}$ ) for SC administration, likely due to longer $\mathrm{t}_{\mathrm{max}}$ versus IV administration [36,38,39]. Maximum proteasome inhibition was measured $1 \mathrm{~h}$ after administration with complete recovery of proteasome activity within $72 \mathrm{~h}$. The relationship between plasma concentration and proteasome inhibition was assessed at 1, 6, and $24 \mathrm{~h}$ over a 24-hour period. Recovery of proteasome activity was observed by $24 \mathrm{~h}$, and the recovery was homogeneous. Interestingly, at $1 \mathrm{~h}$ post-dose, plasma concentration varied by $\sim 800 \%$, while proteasome inhibition varied only by $\sim 70 \%$, indicating a disconnection between plasma concentration and target inhibition [40,41]. It is noteworthy that, despite similar drug exposure and proteasome inhibition levels, the rates of peripheral neuropathy, the adverse event that represents the primary dose limiting toxicity, was reduced in the SC-treated patients versus. Those receiving IV administration of bortezomib likely reflect the different PK profiles [35].

The predominant pathway elimination of bortezomib is through oxidative de-boronation, mostly to a pair of diastereomeric carbinolamide metabolites [42]. In vitro metabolite identification (metID) studies revealed that the major phase 1 metabolic reactions are mediated by cytochrome P450 isomers 3A4 and 2C19, while phase II conjugation pathways do not appear to play any major role in bortezomib metabolism. The inactive deboronated metabolites (M1 and M2) then undergo a series of hydroxylations leading to their elimination. In animals and humans, bortezomib is extensively metabolized with more than 30 metabolites identified, including M1 and M2. Consistent with the in vitro studies, bortezomib is primarily metabolized in vivo via CYP450 enzymes (predominantly 
3A4 and 2D6) and not phase II pathways, such as glucuronidation and sulfation. The major metabolites detected in rat bile and monkey fecal samples were M1 and M2 [43]. These same two metabolites, along with M4, were the major metabolites detected in human plasma, suggesting similar metabolic pathways for bortezomib metabolism in rodents, non-human primates, and humans (Scheme 1). Bortezomib is a poor inhibitor of recombinant CYP450 isozymes 1A2, 2C9, 2C19, 2D6, and 3A4 with $\mathrm{IC}_{50}$ values of greater than $18 \mu \mathrm{M}(\sim 7 \mu \mathrm{g} / \mathrm{mL})$ in human liver microsomes. These $\mathrm{IC}_{50}$ values are 60 -fold higher than the $C_{\max }(89-120 \mathrm{ng} / \mathrm{mL})$ observed in patients treated with labeled dose of $1.3 \mathrm{mg} / \mathrm{m}^{2}$. Therefore, it is unlikely that direct CYP450 inhibition is the mechanism underlying the apparent accumulation of bortezomib in humans following repeat dosing. However, in drug-drug interaction (DDI) studies, patients receiving bortezomib plus ketoconazole, a CYP3A4 inhibitor, revealed an increase in bortezomib exposure by 1.4-fold [44], further indicating the role of CYP3A4 in the metabolism of this drug.<smiles>CC(C)C[C@H](O)NC(=O)[C@H](Cc1ccccc1)NC(=O)c1cnccn1</smiles><smiles>O=C(N[C@@H](Cc1ccccc1)C(=O)O)c1cnccn1</smiles>

M4

Scheme 1. Metabolic pathway of bortezomib by CYPs and hydrolases.

Ixazomib

Ixazomib is an orally bioavailable analog of bortezomib and is approved for the treatment of relapsed multiple myeloma [38]. As in bortezomib, ixazomib preferentially binds 
to and inhibits the chymotrypsin-like activities of the $20 \mathrm{~S}$ proteasome ( $\beta 5$ and LMP7) with 10 - and 1000-fold less potency for caspase-like and trypsin-like activities, respectively. In clinical studies using IV administration, proteasome inhibition in whole blood samples was rapid and dose-dependent and recovered within $24 \mathrm{~h}$ dosing [45]. In patients, ixazomib shows rapid absorption with $\mathrm{T}_{\max }$ of approximately $1 \mathrm{~h}$, low apparent clearance of $\sim 1.9 \mathrm{~L} / \mathrm{h}$ with a $\mathrm{t}_{1 / 2}$ of 9.5 days, and oral bioavailability of $58 \%$. In a phase 1 study in relapsed/refractory lymphoma patients, plasma exposure increased dose proportionally from $0.5-3.11 \mathrm{mg} / \mathrm{m}^{2}$, which was also population PK analysis, and no apparent relationship between oral dose $(0.2-10.6 \mathrm{mg})$ and plasma clearance [46]. At clinically relevant concentrations, no single CYP450 isozymes appear to play dominant role in the clearance of ixazomib using microsomes containing recombinantly expressed human CYP enzymes. However, at higher concentrations, ixazomib was metabolized by multiple CYP isozymes with contributions by CYP3A4 (42\%), CYP1A2 (26\%), and CYP2B6 (16\%). Unlike bortezomib, DDI studies have shown no significant effects of strong inhibitors of CYP3A4 on the exposure to ixazomib. Non-CYP pathways seems to be major contributor for the metabolism of ixazomib [39]. The proposed metabolic pathway of ixazomib is shown in Scheme 2, based on the phase 1 study using ${ }^{14} \mathrm{C}$-ixazomib in patients with advanced solid tumors or lymphoma. Metabolite profiles were similar in plasma, urine, and feces from the four patients after administration of a single $4.1-\mathrm{mg}$ oral dose of $\left[{ }^{14} \mathrm{C}\right]$-ixazomib with total radioactivity (TRA) of $\sim 500 \mathrm{nCi}$. All metabolites identified were de-boronated. Ixazomib (54.2\% of plasma TRA) and metabolites M1 (18.9\%), M2 (7.91\%), M3 (10.6\%) were the primary components in $\mathrm{AUC}_{0-816 \mathrm{~h}}$ time-proportional pooled plasma. Hydrolytic metabolism in conjunction with oxidative de-boronation are the major metabolic pathways for ixazomib [47].<smiles>C=C(C)C[C@H](NC(=O)CNC(=O)c1cc(Cl)ccc1Cl)B(O)O</smiles>

Scheme 2. Metabolic pathway of ixazomib by CYPs and hydrolases. 


\section{Pharmacokinetics, Pharmacodynamics, and Metabolism of Epoxide-Based Proteasome Inhibitors}

\subsection{Carfilzomib}

Carfilzomib is a peptide epoxyketone-based proteasome inhibitor originally derived from the natural product epoxmicin [18]. It is the only approved agent with a reactive epoxide pharmacophore, a feature previously thought unsuitable for drug development [48]. Carfilzomib received initial FDA approval in relapsed and refractory myeloma in 2012 and is currently approved for use with IV administration (predominantly as a 30-min infusion) once or twice weekly at doses ranging from 27 to $70 \mathrm{mg} / \mathrm{m}^{2}$. It is unclear why a broader range of therapeutically active and tolerated doses of carfilzomib are able to be utilized relative to the approved boronate inhibitors, but carfilzomib has been demonstrated to have fewer off-target effects relative to bortezomib [15]. In addition, in a 2 head-to-head study compared to bortezomib, rates of peripheral neuropathy were $>60 \%$ lower in carfilzomibtreated patients $[49,50]$. Carfilzomib cleared rapidly with $t_{1 / 2}$ values of $<30$ min in humans and systemic clearance rates higher than hepatic blood flow, indicating extra-hepatic clearance mechanisms [51]. Exposure to carfilzomib, both maximum and total, increased with the dose but in a manner that was not dose-proportional [52]. Although an irreversible inhibitor, clearance in animals was unaffected with prior administration of another covalent proteasome inhibitor, suggesting that target binding does not mediate the rapid clearance seen in animals and humans [53]. When administrated as a 30-min infusion to rats at $8 \mathrm{mg} / \mathrm{kg}$, the steady state concentration $\left(\mathrm{C}_{\mathrm{ss}}\right)$ was 28 -fold lower than the $\mathrm{C}_{\max }$ in the bolus group at the same dose, while the total exposure (AUC) and proteasome inhibition in blood and tissues were equivalent. These results demonstrate that the level of target inhibition achieved in vivo is correlated with the total dose but not $C_{\max }$ [54].

IV administration of carfilzomib resulted in suppression of proteasome CT-L activity in patients when measured in blood one hour after the first dose. Inhibition of proteasome CT-L activity was comparable in whole blood (predominantly constitutive proteasome) and PBMCs (immunoproteasome), indicating that carfilzomib acts as a dual proteasome inhibitor. Using an active site binding assay called ProCISE [44], first dose inhibition of the $\beta 5$ and LMP7 subunits of the constitutive proteasome and immunoproteasome, respectively, ranged from 67 to $74 \%$ and $77-80 \%$, respectively, at $15 \mathrm{mg} / \mathrm{m}^{2}$ and $20 \mathrm{mg} / \mathrm{m}^{2}$. Inhibition of the LMP2 and MECL-1 subunits of the immunoproteasome ranged from 22 to 33 and 31 to $46 \%$ at $20 \mathrm{mg} / \mathrm{m}^{2}$, respectively. Less than $18 \%$ inhibition of the $\beta 1$ or $\beta 2$ was observed in whole blood samples at doses as high as $45 \mathrm{mg} / \mathrm{m}^{2}$. Measured occupancy of the other subunits increased at $45 \mathrm{mg} / \mathrm{m}^{2}$ dose with most prominent effect on MECL1 and LMP2. Proteasome inhibition was maintained for $\geq 48 \mathrm{~h}$ following the first dose of carfilzomib for each week of dosing. Near-complete recovery of proteasome activity was observed in PBMC between cycles.

Rapid metabolism in vitro by liver microsomes, in the presence of cofactor NADPH, indicated that carfilzomib is a substrate of CYP450 enzymes. However, in animals and humans in vivo, the predominant plasma and urine metabolites are inactive hydrolysis products, including the diol, and less than $1 \%$ of the dose was excreted intact (Scheme 3) [54-56]. Additional and non-traditional studies were carried out in vitro and in vivo to reveal the roles of peptide cleavage and epoxide hydrolysis in the metabolism of carfilzomib [55]. In rat blood and tissue homogenates from liver, lung, and kidney, carfilzomib rapidly disappeared with the formation of 3 metabolites, the inactive diol metabolite M16, and the peptide cleavage products M14 and M15. Pooled plasma and urine samples from a phase 1 trial were used to determine the metabolite fate of carfilzomib following administration. The major metabolites M14, M15, and M16 were derived from peptidase cleavage and epoxide hydrolysis of carfilzomib, and CYP-mediated metabolites were detected only at very low levels [54]. M14 and M15 may have been derived from either carfilzomib or M16 (Scheme 3). In cultured hepatocytes, the diol was the predominant metabolite further supporting the importance of epoxide hydrolysis. Additional studies using recombinant enzymes revealed that microsomal epoxide hydrolase $(\mathrm{mEH})$, and not soluble epoxide 
hydrolase (sEH), is responsible for the formation of M16 (unpublished results). These studies revealed that carfilzomib metabolism is unique and not mediated by standard CYP450 or phase II enzymes. In support of this, there is no apparent alteration in exposure to carfilzomib in patients with impaired hepatic function [57].

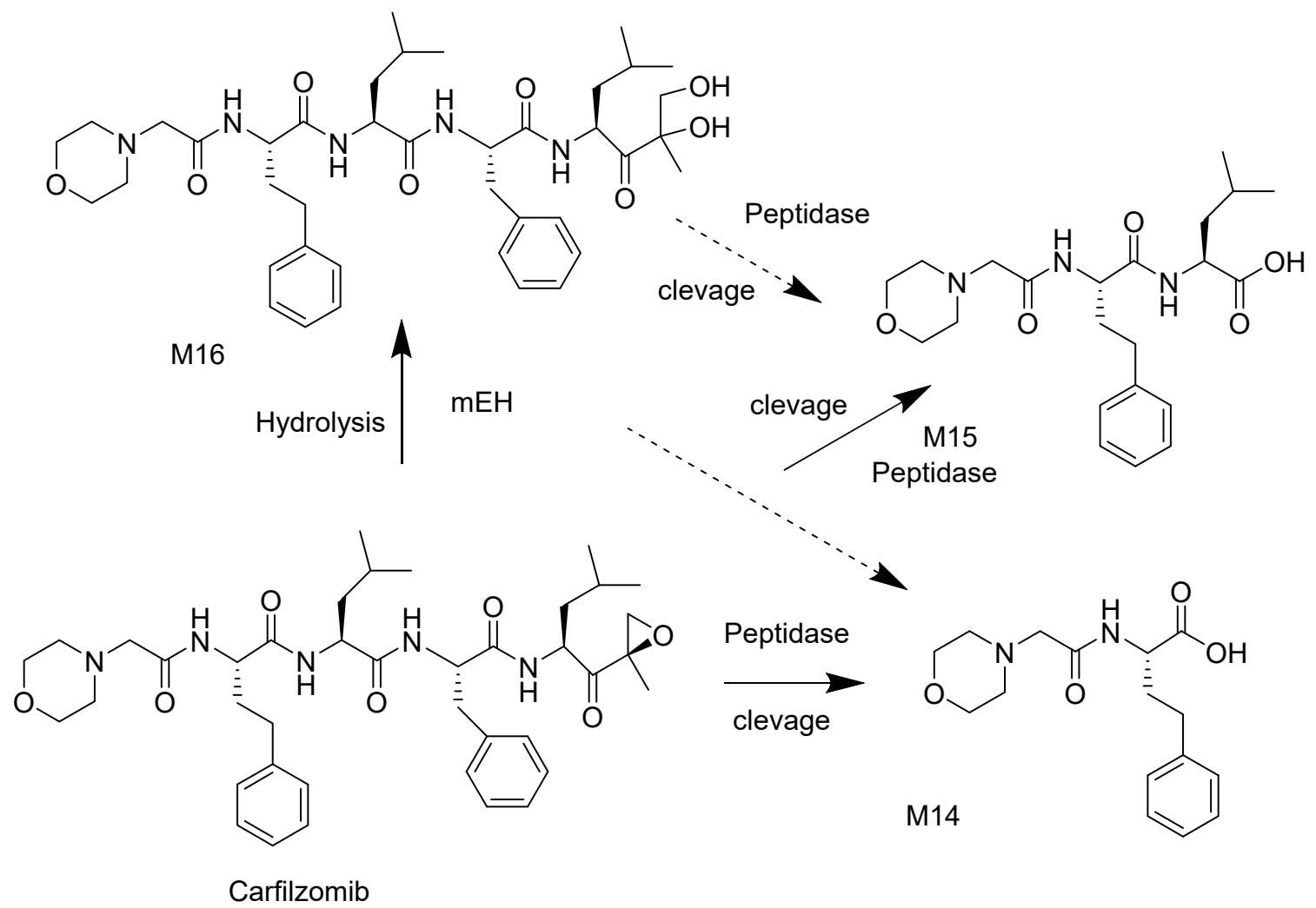

Scheme 3. Metabolic pathway of carfilzomib by microsomal epoxide hydrolase and peptidases.

\subsection{Oprozomib}

As in carfilzomib, oprozomib is a peptide epoxyketone-based proteasome inhibitor and is currently in clinical trials [58]. Oprozomib is a result of a chemistry effort to discover orally bioavailable analogues of carfilzomib which would have potential for improved flexibility in dosing and patient convenience over intravenously administrated agents. The effort focused on structure and activity relationship of short peptide portion of carfilzomib since di- and tripeptides can cross intestinal epithelial barriers, while tetrapeptides are generally not orally bioavailable. The tripeptide oprozomib demonstrated an equivalent potency for 15 and LMP7, displayed selectivity for the chymotrypsin-like (CT-L) subunits over trypsin-like (T-L), and (caspase-like) C-L activities of the proteasome, and promoted an equivalent antitumor response to carfilzomib in mouse models of human tumors. Oprozomib showed improved solubility, metabolic stability and displayed a moderate oral bioavailability with $\mathrm{F} \%$ of 17,21 , and 39 in mice, rats, and dogs, respectively. Oral bioactivity measured by PK and PD was found to be comparable [59]. Oprozomib has shown clinical activity in the patients with hematologic malignancies. The maximum tolerated dose (MTD) of single agent oprozomib was $300 \mathrm{mg} /$ day when administrated the first 2 days every 7 days of a 14-day cycle or $240 \mathrm{mg} /$ day when administrated on the first 5 days of a 14-day cycle. Oprozomib was administrated in capsule and tablet forms in patients with multiple myeloma and as tablets in patients with Waldenström's macroglobulinemia. Absorption was rapid with median $\mathrm{t}_{\max }$ between 0.4 and $2 \mathrm{~h}$, both tablets and capsules. Clearance was also rapid with a mean $t_{1 / 2}$ ranging from 0.52 to $2.5 \mathrm{~h}$ [60]. Exposure to oprozomib increased dose proportionally in patients with multiple myeloma with a high inter-patient variability [61]. Potent proteasome inhibition was 
observed in whole blood $8 \mathrm{~h}$ after administration. At the maximum tolerated dose (MTD; $300 \mathrm{mg}$ /day on the $2 / 7$ schedule and $240 \mathrm{mg}$ /day on the $5 / 14$ schedule), proteasome inhibition was $\geq 70 \% 4 \mathrm{~h}$ post-dose [61].

Metabolic stability of oprozomib was conducted in human hepatocytes, and a predominant diol of oprozomib (PR-176) was formed from direct epoxide hydrolysis. Two metabolites at relatively low levels were observed from peptide bond cleavage: one with $\mathrm{m} / \mathrm{z}$ at 245.0587 (bond 2 cleavage), and the other with $\mathrm{m} / \mathrm{z}$ at 224.1276 (diol od PR-025, bond 1 cleavage). Other trace amount metabolites from hydroxylation and/or de-methylation, direct glutathione (GSH) conjugation, and the combination of oxidation and epoxide hydrolysis or GSH conjugation were also observed. Quantification using synthesized standards revealed that $\sim 55 \%$ of total oprozomib was recovered as the diol, $\sim 7 \%$ recovered as the diol of PR-025, and 20\% remained as oprozomib. These results suggested that epoxide hydrolysis is the major metabolic pathway for oprozomib in human hepatocytes. Metabolic stability of oprozomib in the presence and absence of NADPH was evaluated in human liver microsomes (HLM). In pooled HLMs, the presence of NADPH significantly increased the intrinsic clearance of oprozomib by 3.5-fold compared with that in the absence of $\mathrm{NADPH}(70.7 \pm 2.9$ versus $20.2 \pm 1.8 \mu \mathrm{L} / \mathrm{min} / \mathrm{mg}$ protein), indicating a significant role of oxidation pathways over epoxide hydrolysis in HLMs, which is in contrast with the result observed in human hepatocytes. Recombinant enzyme studies demonstrated that epoxide hydrolysis activity is mediated by $\mathrm{mEH}$, rather than $\mathrm{sEH}$, and the in vitro metabolism is consistent with the findings from in vivo samples (Scheme 4) [62]. There is no published metID from patient samples.

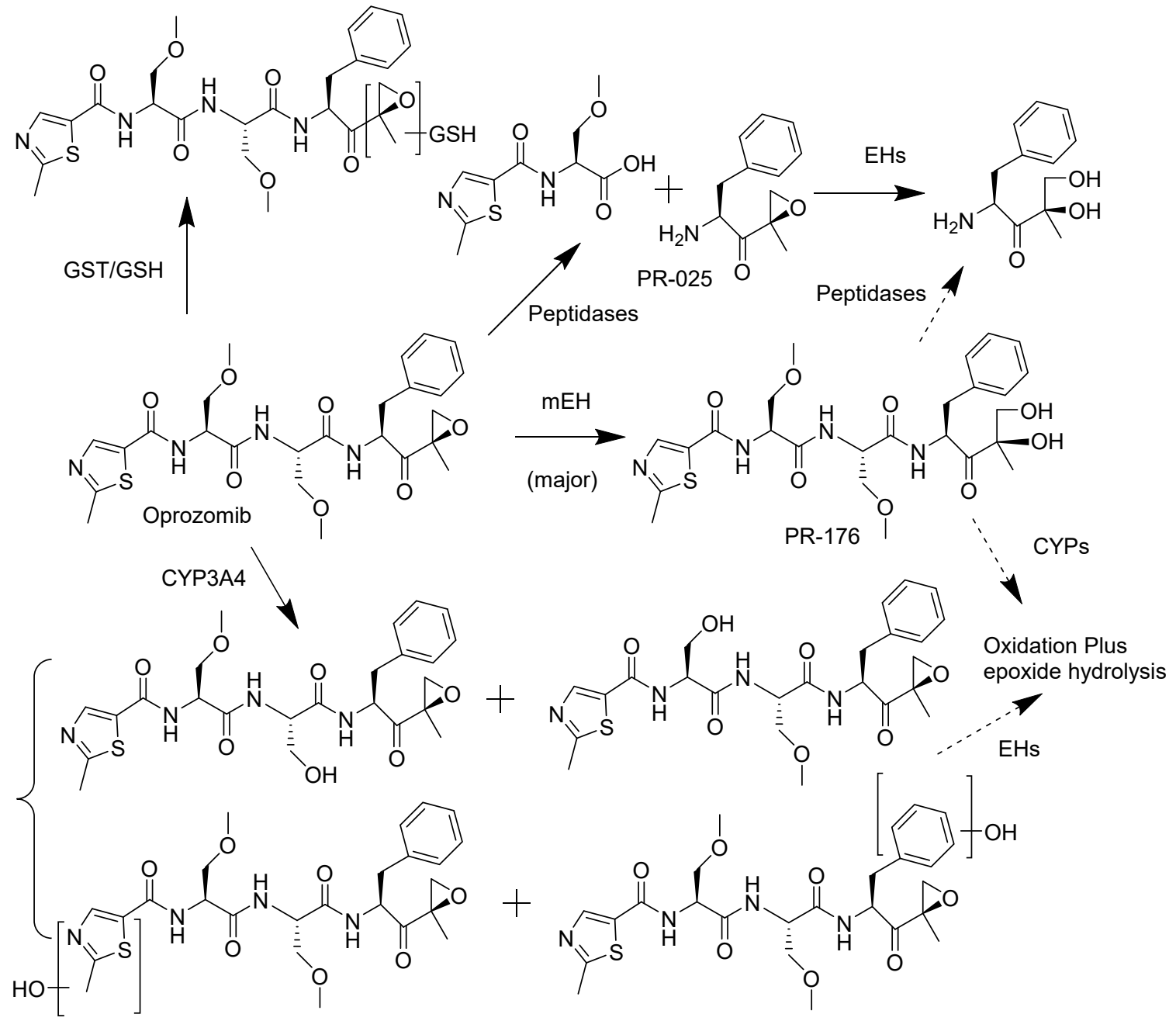

Scheme 4. Metabolic pathway of oprozomib by $\mathrm{mEH}$, peptidases, and CYPs. 


\subsection{KZR-616}

Use of the tool compound ONX 0914 revealed that selective inhibition of the immunoproteasome results in broad and potent anti-inflammatory activity in preclinical models of multiple autoimmune disorders [10,63,64]. KZR-616 is a tripeptide ketoepoxide-based selective inhibitor of the human immunoproteasome that was derived from a medicinal chemistry effort that involved the synthesis of over 400 tripeptide epoxyketones. The design of these inhibitors utilized a human homology model evolved of the murine crystal structure of the ONX 0914/proteasome isoform complexes. The model was developed to elucidate per subunit the optimal recognition of nonprime selectivity pockets (S1, S2, S3) by the amino acid side chains / features (P1, P2, and P3, respectively (Figure 3)) [20]. Profiling of selective inhibitors in PBMCs stimulated to produce cytokines revealed that the inhibition of LMP7 alone was insufficient to inhibit broad cytokine expression and translated to minimal activity in a mouse model of inflammatory arthritis. A combination of LMP7 and LMP2 and/or MECL-1 inhibitors offered an optimal cytokine inhibition profile in vitro, which correlated with in vivo efficacy. It is noteworthy that KZR-616 achieved activity in the mouse arthritis model via complete LMP7 inhibition and $40 \%$ LMP2 inhibition, suggesting that only partial inhibition of a secondary immunoproteasome subunit is sufficient for a multi-cytokine inhibitory effect. The discovery effort also improved the physicochemical properties of KZR-616 for later clinical use [20].

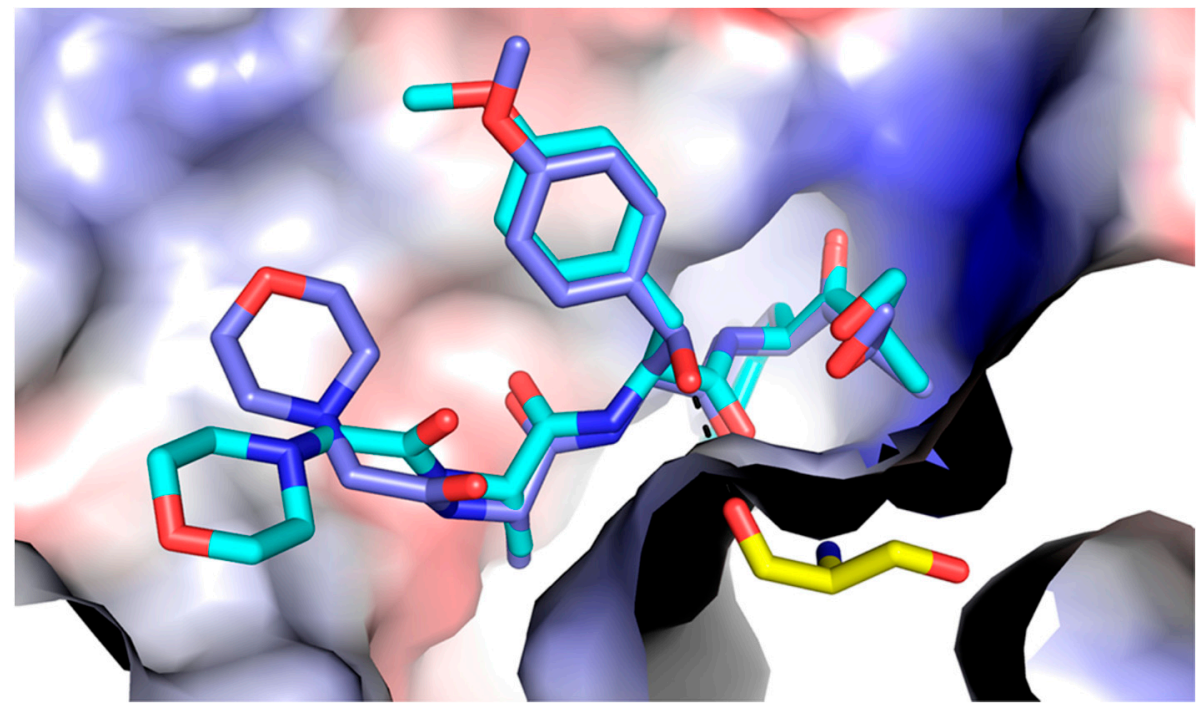

Figure 3. Modeling of KZR-616 (purple) and ONX 0914 (blue) in the LMP7/ $\beta 6$ binding site. Taken from Reference [20].

In healthy volunteers, subcutaneous (SC) administration of KZR-616 demonstrated rapid absorption with a $\mathrm{T}_{\max }<1 \mathrm{~h}$ and rapid clearance with a $\mathrm{t}_{1 / 2}<4 \mathrm{~h}$. Exposure was linear across a 10-fold dose range, and no accumulation was observed with repeated weekly dosing. The bioavailability of SC administration was $70-100 \%$ and low inter-subject variability was noted in total exposure (the major determinant for target inhibition). Across doses of 7.5 to $75 \mathrm{mg}$, mean inhibition of PBMC chymotrypsin-like (CT-L) activity (predominantly immunoproteasome) measured $4 \mathrm{~h}$ post-dose ranged from 56 to $93 \%$. Mean inhibition of whole blood CT-L activity (predominantly constitutive proteasome) ranged from 8 to $43 \%$ across a tested dose range of 7.5 to $60 \mathrm{mg}$, demonstrating that KZR-616 selectively inhibits the immunoproteasome relative to the constitutive proteasome (Figure 4). Following repeat-dose SC administration, there was no apparent accumulation of immunoproteasome inhibition, although cumulative constitutive proteasome inhibition in whole blood was observed, likely due to the irreversible mechanism of KZR-616 inhibition and the inability of enucleated red blood cells (the major cellular source of constitutive proteasome) to produce new proteasomes. PK and PD correlation analysis reveals that immunoprotea- 
some inhibition is related to total $\left(R^{2}=0.712\right)$ rather than maximum $\left.\left(R^{2}=0.464\right)\right)$ exposure (Figure 5) [65]. As in carfilzomib, and oprozomib, KZR-616 was not stable when incubated in HLMs in the absence of NADPH, indicating non-CYP enzymes were involved in its clearance. CYP phenotyping demonstrated that CYP3A4/5 was the major enzyme involved in the microsomal metabolism of KZR-616, with CYP2C8 playing a minor role in its metabolism. Formation of the KZR-616 diol, KZR-59587, was not affected by the presence of CYP inhibitors, demonstrating that other enzymes, such as epoxide hydrolases, play important roles in diol formation. Metabolic profiling using hepatocyte suspensions from rats, monkeys, and humans revealed KZR-59587, was the most predominant metabolite, and no metabolites unique to humans were observed [66]. In pooled plasma samples from 4 patients with systemic lupus erythematous (SLE) receiving a KZR-616 dose of $75 \mathrm{mg}$, the diol was the major metabolite, and other metabolites from oxidation, hydrolysis + dehydrogenation, oxidation + dehydrogenation double oxidation were less than $1 \%$ of the total peak area of all components (Table 2).

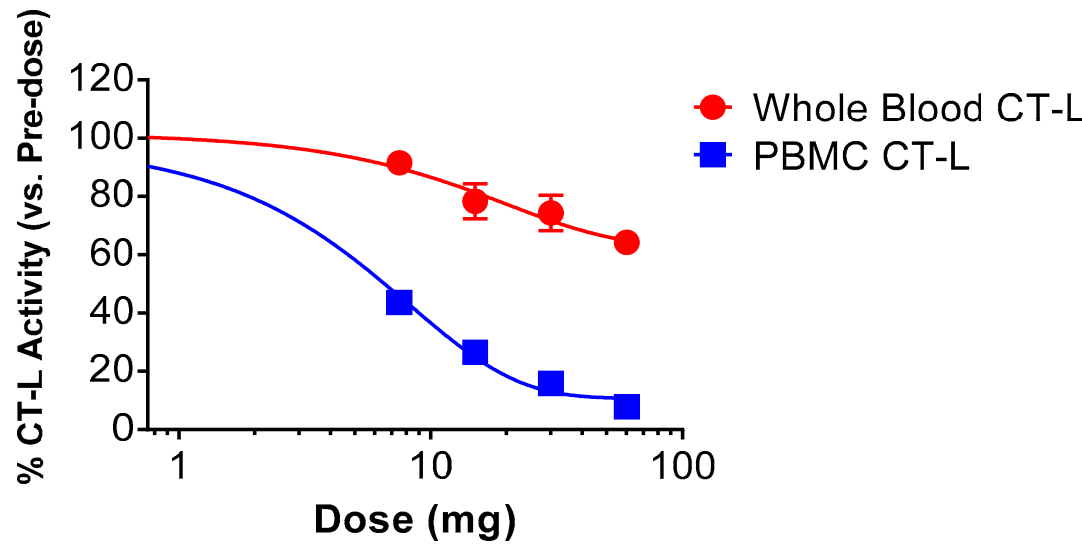

Figure 4. Inhibition of proteasome CT-L activity, $4 \mathrm{~h}$ following a single dose of KZR-616 in SAD cohorts of study KZR-616-001 (Mean \pm SEM; N = 6/group).

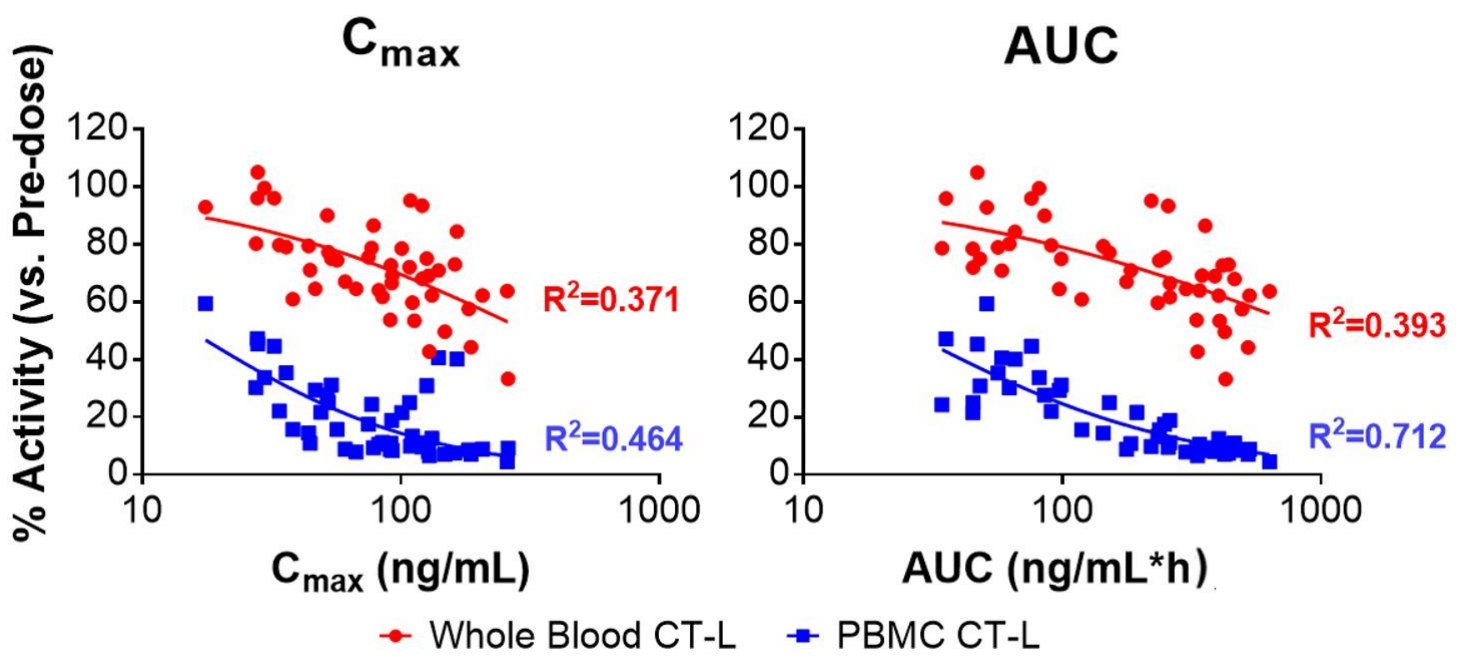

Figure 5. Immunoproteasome inhibition related to total (AUC) exposure, rather than maximum $\left(C_{\max }\right)$ exposure. 
Table 2. Summary of KZR-616 and proposed metabolites observed in human plasma.

\begin{tabular}{|c|c|c|c|c|c|c|c|}
\hline \multirow{3}{*}{ Component Label } & \multirow{3}{*}{ Identification } & \multirow{3}{*}{$\begin{array}{l}\text { Retention } \\
\text { Time (min) }\end{array}$} & \multirow{3}{*}[\mathbf{M}+\mathbf{H}]{$^{+}(m / z)$} & \multicolumn{4}{|c|}{$\begin{array}{l}\text { Component in Plasma as \% of Total a }{ }^{\text {a }} \text { XIC } \\
\text { (Extracted Ion Chromatogram) Area }\end{array}$} \\
\hline & & & & \multicolumn{4}{|c|}{ Subject } \\
\hline & & & & 110-004 & $112-021$ & 113-002 & 116-012 \\
\hline KZR-616 & Parent & 22.0 & 587.3 & 61.2 & 49.0 & 46.5 & 51.8 \\
\hline KZR-59587 & Epoxide hydrolysis & 16.4 & 605.3 & 33.8 & 45.8 & 47.9 & 43.8 \\
\hline M605_2 & Epoxide hydrolysis (isomer) & 14.5 & 605.3 & 0.270 & 0.270 & 0.270 & 0.280 \\
\hline M603_1 & Oxidation & 11.0 & 603.3 & 0.080 & 0.100 & 0.060 & 0.060 \\
\hline M603_7 & Oxidation & 11.8 & 603.3 & 0.100 & 0.250 & 0.040 & 0.170 \\
\hline M603_8 & Oxidation & 13.3 & 603.3 & 0.150 & 0.190 & 0.150 & 0.190 \\
\hline M603_2 & Oxidation & 15.0 & 603.3 & 0.080 & 0.020 & 0.080 & 0.060 \\
\hline M603_3 & Oxidation & 17.5 & 603.3 & 0.140 & 0.110 & 0.150 & 0.100 \\
\hline M603-4 & Hydrolysis + dehydrogenation & 20.2 & 603.3 & 0.280 & 0.420 & 0.290 & 0.240 \\
\hline M603_5 & Hydrolysis + dehydrogenation & 20.4 & 603.3 & 0.260 & 0.260 & 0.280 & 0.240 \\
\hline M603_6 & Oxidation & 22.8 & 603.3 & 0.390 & 0.340 & 0.410 & 0.330 \\
\hline M601 & Oxidation + dehydrogenation & 14.4 & 601.3 & 0.890 & 0.870 & 0.800 & 0.910 \\
\hline M619_1 & Double Oxidation & 9.71 & 619.3 & 0.280 & 0.280 & 0.160 & 0.190 \\
\hline M619_2 & Double Oxidation & 19.1 & 619.3 & 0.120 & 0.170 & 0.030 & 0.020 \\
\hline
\end{tabular}

To further evaluate the role of epoxide hydrolase in the metabolism of KZR-616, two analogs were selected for PK and PD studies in cynomolgus monkey to compare with KZR-616. Relative to KZR-616, KZR-59240 demonstrated increased stability, while KZR59177 demonstrated reduced stability when cultured in liver microsome suspensions in the absence of NADPH. Following single subcutaneous (SC) administration to monkeys at $3 \mathrm{mg} / \mathrm{kg}$ of these 3 compounds AUC values were the highest with KZR-59240, followed by KZR-616 and KZR-59177. The PK of both parent and diol for each compound were consistent with the stability results in MLM in the absence of NADPH, in which the CYP enzymes were not activated (Table 3), and, as predicted, the diol derivatives were determined to be the major metabolites for all compounds. The PK and PD of KZR-616 was assessed using 2 different drug product formulations, one containing $10 \%(w / v)$ PS- 80 , and the other $2 \%(w / v)$ trehalose. PK analysis of this study showed a 2 -fold difference in $\mathrm{C}_{\max }$ but equivalent total exposure (AUC) for KZR-616 in both formulations. Since the PD was roughly equivalent between the 2 different formulations, these data support the hypothesis derived from studies with carfilzomib that target inhibition is an effect of total, but not maximum, drug exposure.

Table 3. PK parameters of KZR-616 and analogs after a single SC dose of $3 \mathrm{mg} / \mathrm{kg}$ in monkeys.

\begin{tabular}{cccc}
\hline ID & KZR-59177 & KZR-616 & KZR-59240 \\
\hline $\mathrm{T}_{1 / 2}(\mathrm{~h})$ & $1.44 \pm 0.420$ & $1.05 \pm 0.130$ & $0.980 \pm 0.264$ \\
$\mathrm{~T}_{\max }(\mathrm{h})$ & $0.792 \pm 0.417$ & $0.333 \pm 0.136$ & $0.500 \pm 0.334$ \\
$\mathrm{C}_{\max }(\mathrm{ng} / \mathrm{mL})$ & $182 \pm 31.5$ & $441 \pm 114$ & $803 \pm 260$ \\
$\mathrm{AUC}_{\text {inf }}\left(\mathrm{h}^{*} \mathrm{ng} / \mathrm{mL}\right)$ & $447 \pm 57.3$ & $740 \pm 188$ & $1412 \pm 279$ \\
AUC Ratio $($ diol/parent $)$ & $3.35 \pm 1.20$ & $3.40 \pm 0.808$ & $0.777 \pm 0.464$ \\
\hline
\end{tabular}

Similar to carfilzomib, mEH-mediated diol formation of KZR-616 (Scheme 5) and was not saturable in vitro. However, unlike both carfilzomib and oprozomib, no peptide cleavage products were identified, suggesting that diol formation is the sole metabolic pathway of KZR-616 in humans. KZR-616 is currently being evaluated in Phase 2 clinical trial in patients with lupus nephritis (LN) (MISSION Study; NCT03393013), as well as polymyositis and dermatomyositis. (PRESIDIO Study; NCT04033926). 


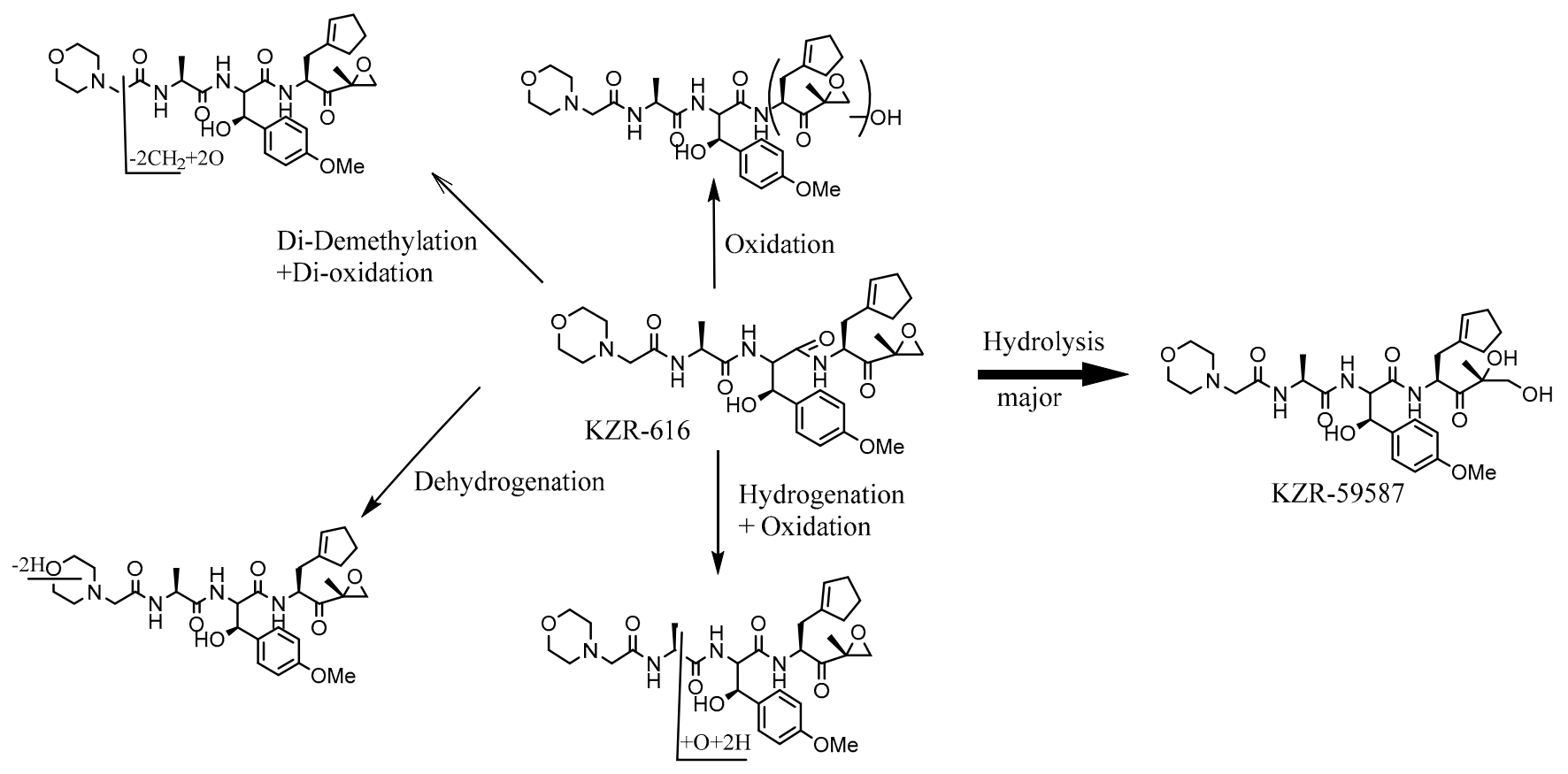

Scheme 5. Metabolic pathway of KZR-616 by mEH.

\section{Discussion and Conclusions}

Small molecule targeting of the catalytic subunits of the proteasome has been a fruitful area of drug discovery and development. Currently approved proteasome inhibitors comprise 2 chemical classes with distinct pathways of metabolism and clearance (Table 1). Despite these differences, boronic acid-based and peptide epoxyketone-based inhibitors all show rapid clearance in animals and humans. However, the pharmacodynamic profile of boronic acid-based and peptide epoxyketone-based inhibitors were different in patients. At doses of carfilzomib routinely used in the clinic (i.e., $\geq 15 \mathrm{mg} / \mathrm{m}^{2}$ ), average inhibition of $\beta 5$ and LMP7 was greater than 83\% [55]. This level of inhibition is higher than the $65-70 \%$ measured in bortezomib-treated patients $[37,40,67]$. There was little to no recovery of proteasome activity in whole blood following the administration of carfilzomib which is consistent with preclinical results in rodents, though this likely does not reflect effects in tissues [18]. Interestingly, the recovery of activity in PBMCs was slower than predicted-based on animal data. Minimal recovery of proteasome activity was seen $24 \mathrm{~h}$ after the first dose, and incomplete recovery was observed after the 5 day non-dosing period during the first week of treatment. In contrast, $50 \%$ recovery of activity was observed $12 \mathrm{~h}$ after administration of bortezomib, with full recovery achieved $36 \mathrm{~h}$ after dosing [68]. The differences in proteasome recovery between the two drugs may be due to the irreversible bonding of carfilzomib in contrast to the reversible binding of bortezomib [55], rather than differences in exposure parameters. While the recovery of proteasome activity in carfilzomib-treated subjects relies completely on new proteasome regeneration, recovery in bortezomib-treated subjects involves both release from bound proteasome active sites and new proteasome generation [52]. Metabolism of bortezomib and ixazomib are mediated by CYP450s, and possibly additional enzymes, while peptide epoxyketone inhibitors, such as carfilzomib and oprozomib, are cleared via epoxide hydrolase activity and peptide hydrolysis. Epoxide hydrolases are a ubiquitously expressed family of enzymes found in mammals [69-72] and are the primary pathway for the detoxification of compounds containing an epoxide residue [73]. There are 2 major isoforms, $\mathrm{mEH}$, encoded by the EPHX1 gene and localized predominantly in the endoplasmic reticulum [74], and sEH, encoded by the EPHX2 gene and confined mainly to cytoplasm [75]. EPHX1 is well recognized as one of the main enzymes detoxifying xenobiotic epoxides. Owning to the high chemical reactivity of these compounds, EPHX1 was considered to be protective against mutagenic and carcinogenic 
initiation. Consequently, EPHX1 inhibition is thought to be rather deleterious, since it increases the toxicity of xenobiotics, as well as the risk of cancer and inflammatory diseases. On the other hand, EPHX2 was shown to orchestrate a variety of physiological functions, by mediating the formation of cytotoxic dihydrodiols at the expense of rather cytoprotective epoxides of fatty acids [76]. Consequently, EPHX2 inhibition emerged as a promising therapy to treat several diseases, including neuropathic pain, diabetic peripheral neuropathy, and averting cytokine storms in COVID-19 [77-79]. However, the reality seems to be more complex. More recently, EPHX1 was shown to play a leading role in the hydrolysis of different fatty acid epoxides [80]. The approval of carfilzomib as the first small molecule containing a reactive epoxide opens up the possibility of additional novel agents containing this reactive pharmacophore. However, additional or alternative studies for metabolism, including the use of tissue homogenates, are required to understand the metabolic fate of these compounds. Interestingly, carfilzomib, oprozomib, and KZR-616 were all found to be substrates of $\mathrm{mEH}$ but not $\mathrm{sEH}$, although their peptide sequence and size are different. The active site of $\mathrm{mEH}$ harbors two conserved tyrosine residues which may contribute to substrate specificity and orientation of substrates within the active site [81]. The epoxide ring in these three proteasome inhibitors can fit into the active pocket of $\mathrm{mEH}$ with a right position suitable for hydrolysis to form the corresponding inactive diols [82]. CYPs play minimal role for the metabolism of proteasome inhibitors containing epoxide moiety. Metabolic findings using liver microsomes should be interpreted with caution since the microsomal system may be biased toward P450-mediated metabolism and may underestimate non-P450 metabolism. It is also noteworthy that KZR-616 was not subject to peptide hydrolysis as a means of metabolism. This singular and non-saturable metabolic pathway may help explain the consistent PK noted in humans thus far and may prove to be a salient feature for its use as a long-term chronic therapy (Table 1).

Author Contributions: Conceptualization, J.W.; data curation, J.W., Y.F. and R.A.F.; writing-original draft preparation, J.W.; writing-review and editing, J.W., C.J.K. and R.A.F. All authors have read and agreed to the published version of the manuscript.

Funding: The work was supported by Kezar Life Sciences.

Institutional Review Board Statement: Not Applicable.

Informed Consent Statement: Not Applicable.

Data Availability Statement: Not applicable.

Acknowledgments: We thank Kiruthi Palaniswamy, Michelle Greenman, and Mark Shiller from Kezar Life Sciences for reviewing the manuscript and helpful suggestions.

Conflicts of Interest: The authors declare that they have no competing interests.

\section{References}

1. Demartino, G.N.; Gillette, T.G. Proteasomes: Machines for all reasons. Cell 2007, 129, 659-662. [CrossRef] [PubMed]

2. Park, J.; Cho, J.; Song, E.J. Ubiquitin-proteasome system (UPS) as a target for anticancer treatment. Arch. Pharm. Res. 2020, 43, 1144-1161. [CrossRef]

3. Khalil, R. Ubiquitin-proteasome pathway and muscle atrophy. Adv. Exp. Med. Biol. 2018, 1088, 235-248. [PubMed]

4. Narayanan, S.; Cai, C.Y.; Assaraf, Y.G.; Guo, H.Q.; Cui, Q.; Wei, L.; Huang, J.J.; Ashby, C.R., Jr.; Chen, Z.S. Targeting the ubiquitin-proteasome pathway to overcome anti-cancer drug resistance. Drug Resist Updat. 2020, 48, 100663. [CrossRef] [PubMed]

5. Cao, J.; Zhong, M.B.; Toro, C.A.; Zhang, L.; Cai, D. Endo-lysolsomal pathway and ubiquitin-proteasome system dysfunction in Alzheimer's disease pathogenesis. Neurosci Lett. 2019, 703, 68-78. [CrossRef]

6. Kudriaeva, A.A.; Belogurov, A.A. Proteasome: A nanomachinery of creative destruction. Biochemistry 2019, 84, 159-192. [CrossRef] [PubMed]

7. Parlati, F.; Lee, S.J.; Aujay, M.; Suzuki, E.; Levitsky, K.; Lorens, J.B.; Micklem, D.R.; Ruurs, P.; Sylvain, C.; Lu, Y.; et al. Carfilzomib can induce tumor cell death through selective inhibition of the chymotrypsin-like activity of the proteasome. Blood 2009, 114, 3439-3447. [CrossRef] [PubMed]

8. Cromm, P.M.; Crews, C.M. The proteasome in modern drug discovery: Second life of a highly valuable drug target. ACS Cent Sci. 2017, 3, 830-838. [CrossRef] [PubMed] 
9. Morozov, A.V.; Karpov, V.L. Proteasomes and several aspects of their heterogeneity relevant to cancer. Front. Oncol. 2019,9 , 761. [CrossRef]

10. Muchamuel, T.; Basler, M.; Aujay, M.A.; Suzuki, E.; Kalim, K.W.; Lauer, C.; Sylvain, C.; Ring, E.R.; Shields, J.; Jiang, J.; et al. A selective inhibitor of the immunoproteasome subunit LMP7 blocks cytokine production and attenuates progression of experimental arthritis. Nat. Med. 2009, 15, 781-787. [CrossRef]

11. Eskandari, S.K.; Seelen, M.A.J.; Lin, G.; Azzi, J.R. The immunoproteasome: An old player with a novel and emerging role in alloimmunity. Am. J. Transplant. 2017, 17, 3033-3039. [CrossRef]

12. Xi, J.; Zhuang, R.; Kong, L.; He, R.; Zhu, H.; Zhang, J. Immunoproteasome-selective inhibitors: An overview of recent developments as potential drugs for hematologic malignancies and autoimmune diseases. Eur. J. Med. Chem. 2019, $182,111646$. [CrossRef] [PubMed]

13. Tundo, G.R.; Sbardella, D.; Santoro, A.M.; Coletta, A.; Oddone, F.; Grasso, G.; Milardi, D.; Lacal, P.M.; Marini, S.; Purrello, R.; et al. The proteasome as a druggable target with multiple therapeutic potentialities: Cutting and non-cutting edges. Pharmacol. Ther. 2020, 213, 107579. [CrossRef]

14. Bross, P.F.; Kane, R.; Farrell, A.T.; Abraham, S.; Benson, K.; Brower, M.E.; Bradley, S.; Gobburu, J.V.; Goheer, A.; Lee, S.L.; et al. Approval summary for bortezomib for injection in the treatment of multiple myeloma. Clin. Cancer Res. 2004, 10, 3954-3964. [CrossRef]

15. Herndon, T.M.; Deisseroth, A.; Kaminskas, E.; Kane, R.C.; Koti, K.M.; Rothmann, M.D.; Habtemariam, B.; Bullock, J.; Bray, J.D.; Hawes, J. U.S. Food and Drug Administration Approval: Carfilzomib for the Treatment of Multiple. Clin. Cancer Res. 2013, 19, 4559-4563. [CrossRef]

16. Kumar, S.K.; Jacobus, S.J.; Cohen, A.D.; Weiss, M.; Callander, N.; Singh, A.K.; Parker, T.L.; Menter, A.; Yang, X.; Parsons, B.; et al. Carfilzomib or bortezomib in combination with lenalidomide and dexamethasone for patients with newly diagnosed multiple myeloma without intention for immediate autologous stem-cell transplantation (ENDURANCE): A multicentre, open-label, phase 3, randomized, controlled trial. Lancet Oncol. 2020, 21, 1317-1330. [PubMed]

17. Dimopoulos, M.A.; Goldschmidt, H.; Niesvizky, R.; Joshua, D.; Chng, W.J.; Oriol, A.; Orlowski, R.Z.; Ludwig, H.; Facon, T.; Hajek, R.; et al. Carfilzomib or bortezomib in relapsed or refractory multiple myeloma (ENDEAVOR): An interim overall survival analysis of an open-label, randomized, phase 3 trial. Lancet Oncol. 2017, 18, 1327-1337. [CrossRef]

18. Demo, S.D.; Kirk, C.J.; Aujay, M.A.; Buchholz, T.J.; Dajee, M.; Ho, M.N.; Jiang, J.; Laidig, G.J.; Lewis, E.R.; Parlati, F.; et al. Antitumor Activity of PR-171, a Novel Irreversible Inhibitor of the Proteasome. Cancer Res. 2007, 67, 6383-6391. [CrossRef]

19. Kapur, S.A.; Anderl, J.L.; Kraus, M.; Parlati, F.; Shenk, K.D.; Lee, S.J.; Muchamuel, T.; Bennett, M.K.; Driessen, C., 3rd; Ball, A.J.; et al. Non-proteasomal Targets of the Proteasome Inhibitors Bortezomib and Carfilzomib: A Link to Clinical. Clin. Cancer Res. 2011, 17, 2734-2743. [CrossRef] [PubMed]

20. Johnson, H.W.B.; Lowe, E.; Anderl, J.L.; Fan, A.; Muchamuel, T.; Bowers, S.; Moebius, D.C.; Kirk, C.; McMinn, D.L. Required Immunoproteasome Subunit Inhibition Profile for Anti-Inflammatory Efficacy and Clinical Candidate KZR-616 ((2S,3R)-N-((S)-3-(Cyclopent-1-en-1-yl)-1-((R)-2-methyloxiran-2-yl)-1oxopropan-2-yl)-3-hydroxy-3-(4-methoxyphenyl)-2-((S)-2(2morpholinoacetamido)propanamido)propenamide). J. Med. Chem. 2018, 61, 11127-11143. [PubMed]

21. De Cesco, S.; Kurian, J.; Dufresne, C.; Mittermaier, A.K.; Moitessier, N. Covalent inhibitors design and discovery. Eur. J. Med. Chem. 2017, 138, 96-114. [CrossRef]

22. De Vita, E. 10 Years into the resurgence of covalent drugs. Future Med. Chem. 2021, 13, 193-210. [CrossRef]

23. Strelow, J.M. A perspective on the kinetics of covalent and irreversible inhibition. SLAS Discov. 2017, 22, 3-20. [CrossRef]

24. Groll, M.; Kim, K.B.; Kairies, N.; Huber, R.; Crews, G.M. Crystal structure of epoxomicin: 20S proteasome reveals a molecular basis for selectivity of -epoxyketone proteasome inhibitors. J. Am. Chem. Soc. 2000, 122, 1237-1238. [CrossRef]

25. Nunes, A.T.; Annunziata, C.M. Proteasome inhibitors: Structure and function. Semin Oncol. 2017, 44, 377-380. [CrossRef] [PubMed]

26. Schrader, J.; Henneberg, F.; Mata, R.A.; Tittmann, K.; Schneider, T.R.; Stark, H.; Bourenkov, G.; Chari, A. The inhibition mechanism of human 20S proteasomes enables next-generation inhibitor design. Science 2016, 353, 594-598. [CrossRef] [PubMed]

27. Fricker, L.D. Proteasome Inhibitor Drugs. Annu. Rev. Pharmacol. Toxicol. 2020, 60, 457-476. [CrossRef] [PubMed]

28. Basler, M.; Li, J.; Groettrup, M. On the role of the immunoproteasome in transplant rejection. Iunogenetics 2019, 71, $263-271$. [CrossRef]

29. Muchamuel, T.; Anderl, J.; Fan, R.A.; Johnson, H.W.B.; Kirk, C.J.; Lowe, E. KZR-616, a selective inhibitor of the immunoproteasome, Blocks the disease progression in multiple models of systemic lupus Erythematosus (SLE). In Proceedings of the ACR/ARHP Annual Meeting 2, ACR Poster 2559, New Orleans, LA, USA, 3-8 November 2017.

30. Huber, E.M.; Basler, M.; Schwab, R.; Heinemeyer, W.; Kirk, C.J. Immuno-and constititive proteasome crystal structures reveal differences in substrate and inhibitor specificity. Cell 2012, 148, 727-738. [CrossRef]

31. Groll, M.; Ditzel, L.; Lowe, J.; Stock, D.; Bochtler, M.; Bartunik, H.D.; Huber, R. Structure of $20 S$ proteasome from yeast at $2.4 \AA$ resolution. Nature 1997, 386, 463-471. [CrossRef]

32. Harshbarger, W.; Miller, C.; Diedrich, C.; Sacchettini, J. Crstal structure of the human 20 S proteasome in complex with carfilzomib. Structure 2015, 23, 418-424. [CrossRef] [PubMed]

33. Thibaudeau, T.A.; Smith, D.M. A practical review of proteasome pharmacology. Pharmacol. Rev. 2019, 71, 170-197. [CrossRef] [PubMed] 
34. Park, J.E.; Miller, Z.; Jun, Y.; Lee, W.; Kim, K.B. Next-generation proteasome inhibitors for cancer therapy. Transl. Res. 2018, 198, $1-16$.

35. Moreau, P.; Pylypenko, H.; Grosicki, S.; Karamanesht, L.; Leleu, X.; Grishunina, M.; Pekhtman, G.; Masliak, Z.; Robak, T.; Shubina, A.; et al. Subcutaneous versus intravenous administration of administration of bortezomib in patients with relapsed multiple myeloma: A randomized, phase 3, non-inferiority study. Lancet Oncol. 2011, 12, 431-440. [CrossRef]

36. Tan, C.R.C.; Abdul-Majeed, S.; Cael, B.; Barta, S.K. Clinical Pharmacokinetics and Pharmacodynamics of Bortezomib. Clin. Pharmacokinet. 2019, 58, 157-168. [CrossRef] [PubMed]

37. Orlowski, R.Z.; Stinchcombe, T.E.; Mitchell, B.S.; Shea, T.C.; Baldwin, A.S.; Stahl, S.; Adams, J.; Esseltine, D.L.; Elliott, P.J.; Pien, C.S.; et al. Phase I trial of the proteasome inhibitor PS-341 in patients with refractory hematologic malignancies. J. Clin. Oncol. 2002, 20, 4420-4427. [CrossRef] [PubMed]

38. Zhang, L.; Mager, D.E. Population-based meta-analysis of bortezomib exposure-response relationships in multiple myeloma patients. J. Pharmacokinet. Pharmacodyn. 2020, 47, 77-90. [CrossRef]

39. Moreau, P.; Karamanesht, L.I.; Domnikova, N.; Kyselyova, M.Y.; Vilchevska, K.V.; Doronin, V.A.; Schmidt, A.; Hulin, C.; Leleu, X.; Esseltine, D.L.; et al. Administration of Bortezomib in patients with relapsed multiple myeloma. Clin. Pharmcokinet. 2012, 51, 823-829. [CrossRef]

40. Papandreou, C.N.; Daliani, D.D.; Nix, D.; Yang, H.; Madden, T.; Wang, X.; Pien, C.S.; Millikan, R.E.; TU, S.; Pagliaro, L.; et al. Phase I trial of the proteasome inhibitor bortezomib in patients with advanced solid tumors with observations in androgen-independent prostate cancer. J. Clin. Oncol. 2004, 22, 2107-2121. [CrossRef]

41. Reece, D.E.; Sullivam, D.; Lonial, S.; Mohrbacher, A.F.; Chatta, G.; Shustik, C.; Burris, H.; Venkatakrishnan, K.; Neuwirth, R.W.J.; Karl, M.; et al. Pharmacokinetics and pharmacodynamic study of two doses of bortezomib in patients with relapsed multiple myeloma. Cancer Chemother Pharmocol. 2011, 67, 57-67. [CrossRef] [PubMed]

42. Pekol, T.; Daniels, J.S.; Labutti, J.; Parsons, I.; Nix, D.; Baronas, E.; Hsieh, F.; Gan, L.; Miwa, G. Human metabolism of the proteasome inhibitor bortezomib: Identification of circulating metabolites. Drug Metab Dispos. 2005, 33, 771-777. [CrossRef]

43. Lu, C.; Gallegos, R.; Li, P.; Xia, C.Q.; Pusalkar, S.; Uttamsingh, V.; Nix, D.; Miwa, G.T.; Gan, L. Investigation of drug-drug interaction potential of bortezomib in vivo in female Sprague-dawley rats and in vitro in human microsomes. Drug Metab Dispos. 2006, 34, 702-708. [CrossRef]

44. Venkatakrishnan, K.; Rader, M.; Ramamathan, R.K.; Ramalingam, S.; Chen, E.; Riordan, W.; Trepicchio, W.; Coope, M.; Karol, M.; Von Moltke, L.; et al. Effect of the CYP3A inhibitor ketoconazole on the pharmacokinetics and pharmacodynamics of bortezomib in patients with advance solid tumors: A prospective, multicenter, open-label, randomized, two-way crossover drug-drug interaction study. Clin. Therapeutics. 2009, 31, 2444-2458. [CrossRef]

45. Gupta, N.; Hanley, M.J.; Xia, C.; Labotka, R.; Harvey, R.D.; Venkatakrishnan, K. Pharmacology of Ixazomib: The first oral proteasome inhibitor. Clin. Pharmacokinet. 2019, 58, 431-449. [CrossRef] [PubMed]

46. Assouline, S.E.; Chang, J.; Cheson, B.D.; Rifkin, R.; Hamburg, S.; Reyes, R.; Hui, A.-M.; Yu, J.; Gupta, N.; Di Bacco, A.; et al. Phase I dose-escalation study of IV ixazomib, an investigational proteasome inhibitor, in patients with relapsed/refractory lymphoma. Blood Cancer J. 2014, 4, e251. [CrossRef] [PubMed]

47. Pusalkar, S.; Plesescu, M.; Gupta, N.; Hanley, M.; Venkakakrishnan, K.; Wu, J.; Xia, C.; Zhang, X.; Chowdhury, S. Biotransformation of $\left[{ }^{14} \mathrm{C}\right]$-ixazomib in patients with advanced solid tumors: Characterization of metabolite profiles in plasma, urine, and feces. Cancer Chemother. Pharmacol. 2018, 82, 803-814. [CrossRef]

48. Kim, K.B.; Crews, C.M. From epoxomicin to carfilzomib: Chemistry, biology, and medical outcomes. Nat. Prod. Rep. 2013, 30, 600-604. [CrossRef] [PubMed]

49. Dimopoulos, M.A.; Moreau, P.; Palumbo, A.; Joshua, D.; Pour, L.; Hájek, R.; Facon, T.; Ludwig, H.; Oriol, A.; Goldschmidt, H.; et al. Carfilzomib and dexamethasone versus bortezomib and dexamethasone for patients with relapsed or refractory multiple myeloma (ENDEAVOR): A randomized, phase 3, open-label, multicentre study. Lancet Oncol. 2016, 17, 27-38. [CrossRef]

50. Facon, T.; Lee, J.H.; Moreau, P.; Niesvizky, R.; Dimopoulos, M.; Hajek, R.; Pour, L.; Jurczyszyn, A.; Qiu, L.; Klippel, Z.; et al. Carfilzomib or bortezomib with melphalan-prednisone for transplant-ineligible patients with newly diagnosed multiple myeloma. Blood 2019, 133, 1953-1963. [CrossRef]

51. Alsina, M.; Trudel, S.; Furman, R.R.; Rosen, P.J.; O'Connor, O.A.; Comezo, R.L.; Wong, A.; Kunkel, L.A.; Molineaux, C.J.; Goy, A. A phase 1 single-agent study of twice-weekly consecutive-day dosing of the proteasome inhibitor carfilzomib in patients with relapsed or refractory multiple myeloma or lymphoma. Clin. Cancer Res. 2012, 18, 4830-4840. [CrossRef] [PubMed]

52. O'Connor, O.A.; Stewart, A.K.; Vallone, M.; Molineaux, C.J.; Kunkel, L.A.; Gerecitano, J.F.; Orlowski, R.Z. A phase 1 dose escalation study of the safety and pharmacokinetics of the novel proteasome inhibitor carfilzomib (PR-171) in patients with hematologic malignancies. Clin. Cancer Res. 2009, 15, 7085-7091. [CrossRef] [PubMed]

53. Lee, S.J.; Levitsky, K.; Parlati, F.; Bennett, M.K.; Arastu-Kapur, S.; Kellerman, L.; Woo, T.F.; Wong, A.F.; Papadopoulos, K.P.; Nesvizky, R.; et al. Clinical activity of carfilzomib correlates with inhibition of multiple proteasome subunits: Application of a novel pharmacodynamic assay. Br. J. Haematol. 2016, 173, 884-895. [CrossRef] [PubMed]

54. Yang, J.; Wang, Z.; Fang, Y.; Jiang, J.; Zhao, F.; Wong, H.; Bennett, M.K.; Molineaux, C.J.; Kirk, C.J. Pharmacokinetics, Pharmacodynamics, Metabolism, Distribution, and Excretion of Carfilzomib in Rat. Drug Metab Dispos. 2011, 39, 1873-1882. [CrossRef] 
55. Brown, J.; Plummer, R.; Bauer, T.M.; Anthony, S.; Sarantopoulos, J.; De Vos, F.; White, M.; Schupp, M.; Ou, Y.; Vaishampayan, U. Pharmacokinetics of carfilzomib in patients with advanced malignancies and varying degrees of hepatic impairment: An open-label, single-arm, phase 1 study. Exp. Hematol. Oncol. 2017, 6, 27. [CrossRef]

56. Wang, Z.; Yang, J.; Kirk, C.; Fang, Y.; Alsina, M.; Badros, A.; Papadopoulos, K.; Wong, A.; Woo, T.; Bomb, D.; et al. Clinical pharmacokinetics, metabolism, and drug-drug interaction of carfilzomib. Drug Metab Dispos. 2013, 41, 230-237. [CrossRef] [PubMed]

57. Quach, H.; White, D.; Spencer, A.; Ho, P.J.; Bhutani, D.; White, M.; Inamdar, S.; Morris, C.; Ou, Y.; Gyger, M. Pharmacokinetics and safety of carfilzomib in patients with relapsed multiple myeloma and end-stage renal disease (ESRD): An open-label, single-arm, phase1 study. Cancer Chemother Pharmacol. 2017, 79, 1067-1076. [CrossRef]

58. Infante, J.R.; Mendelson, D.S.; Burris, H.A., 3rd; Bendell, J.C.; Tolcher, A.W.; Gordon, M.S.; Gillenwater, H.H.; Arastu-Kapur, S.; Wong, H.L.; Papadopoulos, K.P. A first-in-human dose-escalation study of the oral proteasome inhibitor Oprozomib in patients with advanced solid tumors. Investig. New Drugs 2016, 34, 216-224. [CrossRef] [PubMed]

59. Zhou, H.J.; Aujay, M.A.; Bennett, M.K.; Dajee, M.; Demo, S.D.; Fang, Y.; Ho, M.N.; Jiang, J.; Kirk, C.J.; Laidig, G.J.; et al. Design and synthesis of an orally bioavailable and selective peptide epoxyketone proteasome inhibitor (PR-047). J. Med. Chem. 2009, 52, 3028-3038. [CrossRef]

60. Ou, Y.; Xu, Y.; Gore, L.; Harvey, R.D.; Mita, A.; Papadopoulos, K.P.; Wang, Z.; Cutler, R.E., Jr.; Pinchasik, D.E.; Tsimberidou, A.M. Physiologically-based pharmacokinetic modelling to predict oprozomib CYP3A drug-drug interaction potential in patients with advanced malignancies. Br. J. Clin. Pharmacol. 2019, 85, 530-539. [CrossRef] [PubMed]

61. Ghobrial, I.M.; Vij, R.; Siegel, D.; Badros, A.; Kaufman, J.; Raje, N.; Jakubowiak, A.; Savona, M.R.; Obreja, M.; Berdeja, J.G. A phase $1 \mathrm{~b} / \mathrm{II}$ study of oprozomib in patients with advanced multiple myeloma and Waldenström Macroglobulinemia. Clin. Cancer Res. 2019, 25, 4907-4916. [CrossRef]

62. Wang, Z.; Fang, Y.; Teague, J.; Wong, H.; Morisseau, C.; Hammock, B.D.; Rock, D.A.; Wang, Z. In Vitro Metabolism of Oprozomib, an Oral Proteasome Inhibitor: Role of Epoxide Hydrolases and Cytochrome P450s. Drug Metab Dispos. 2017, 45, 712-720. [CrossRef] [PubMed]

63. Zerfast, B.L.; Maresh, M.E.; Trader, D.J. The immunoproteasome: Am emerging target in cancer and autoimmune and neurological disorders. J. Med. Chem. 2020, 63, 1841-1858. [CrossRef]

64. Huber, E.M.; Groll, M. A nut for every bolt: Subunit-selective inhibitors of the immunoproteasome ad their therapeutic potential. Cells 2021, 10, 1929. [CrossRef]

65. Lickliter, J.; Bomba, D.; Anderl, J.L.; Kirk, C.J.; Wang, J. KZR-616, a selective inhibitor of the immunoproteasome, shows a promising safety and target inhibition profile in a phase I, double-blind, single (SAD) and multiple ascending dose (MAD) study in healthy volunteers. In Proceedings of the ACR/ARHP Auuual Meeting Poster, ACR Poster 2587, New Orleans, LA, USA, 19-24 October 2018.

66. Fang, Y.; Johnson, H.; Anderl, J.L.; Muchamuel, T.; McMinn, D.; Morisseau, C.; Hammock, B.D.; Kirk, C.; Wang, J. Role of epoxide hydrolases and cytochrome P450s on metabolism of KZR-616, 1 first-in-class selective inhibitor of the immunoproteasome. Drug Metab Dispos. 2021, 49, 810-821. [CrossRef] [PubMed]

67. Moreau, P.; Coiteux, V.; Hulin, C.; Leleu, X.; van de Velde, H.; Acharya, M.; Harousseau, J.L. Prospective comparison of subcutaneous versus intravenous administration of bortezomib in patients with multiple myeloma. Haematologica 2008, 93, 1908-1911. [CrossRef]

68. Hellmann, A.; Rule, S.; Walewski, J.; Shpiberg, O.; Feng, H.; van de Velde, H.; Patel, H.; Skee, D.M.; Girgis, S.; Louw, V.J.; et al. Effect of cytochrome P450 3A4 inducers on the pharmacokinetic, pharmacodynamic and safety profiles of bortezomib in patients with multiple myeloma or non-Hodgkin's lymphoma. Clin. Pharmacokinet. 2011, 50, 781-791. [CrossRef]

69. Wagner, K.M.; Gomes, A.; McReynolds, C.B.; Hammock, B.D. Soluble epoxide hydrolase regulation of lipid mediators limits pain. Neurotherapeutics 2020, 17, 900-916. [CrossRef] [PubMed]

70. Kodani, S.D.; Morisseau, C. Role of epoxy-fatty acids and epoxide hydrolases in the pathology of neuro-inflammation. Biochimie 2019, 159, 59-65. [CrossRef] [PubMed]

71. Gautheron, J.; Jeru, I. The multifaceted role of epoxide hydrolases in human health. Int. J. Mol. Sci. 2021, 22, 13. [CrossRef] [PubMed]

72. Wang, Q.; Xu, X.; Cong, X.; Zeng, Z.; Xu, L.; Luo, X. Interactions between polycyclic aromatic hydrocarbons and epoxide hydrolase 1 play roles in asthma. Environ. Geochem. Health 2019, 41, 191-210. [CrossRef]

73. Abdull Razis, A.F.; Konsure, N.; Loannides, C. Isothiocynates and xenobiotic detoxifiction. Mol. Nutr. Food Res. 2018, 62, e1700916. [CrossRef]

74. Coller, J.K.; Fritz, P.; Zanger, U.M.; Siegle, I.; Eichelbaum, M.; Kroemer, H.K.; Mürdter, T.E. Distribution of microsomal epoxide hydrolase in humans: An immunohistochemical study in normal tissues, and benign and malignant tumours. Histol. J. 2001, 33, 329-336.

75. Larsson, C.; White, I.; Johansson, C.; Stark, A.; Meijer, J. Localization of the human soluble epoxide hydrolase gene (EPHX2) to chromosomal region 8p21-p12. Hum. Genet. 1995, 95, 356-358. [CrossRef]

76. El-Sherbeni, A.A.; El-Kadi, A.O.S. The role of epoxide hydrolases in health and disease. Arch. Toxicol. 2014, 88, 2013-2032. [CrossRef] 
77. Xia, R.; Sun, L.; Liao, J.; You, X.; Xu, D.; Yang, J.; Hwang, S.H.; Jones, R.D.; Hammock, B.; Yang, G. Inhibition of pancreatic carcinoma growth through enhancing $\omega-3$ epoxy polyunsaturated fatty acid profile by inhibition of soluble epoxide hydrolase. Anticancer Res. 2019, 39, 3651-3660. [CrossRef]

78. Paigrahy, D.; Gartung, A.; Yang, J.; Yang, H.; Gilligan, M.M.; Sulciner, M.L.; Bhasin, S.S.; Bielenberg, D.R.; Chang, J.; Schmidt, B.A.; et al. Preoperative stimulation of resolution and inflammation blockade eradicates micrometastases. J. Clin. Investig. 2019, 129, 2964-2979. [CrossRef]

79. Panigraphy, D.; Gilligan, M.M.; Huamg, S.; Gartung, A.; Cortés-Puch, I.; Sime, P.J.; Phipps, R.P.; Serhan, C.N.; Hammock, B.D. Inflammation resolution: A dual-pronged approach to averting cytokine storms in COVID-19? Cancer Metastasis Rev. 2020, 39, 337-340. [CrossRef]

80. Edin, M.L.; Hamedani, B.G.; Gruzdev, A.; Graves, J.P.; Lih, F.B.; Arbes, S.J.; Singh, R.; Leon, A.C.O.; Bradbury, J.A. Epoxide hydrolase 1 (EPHX1) hydrolyzes epoxyeicosanoids and impairs cardiac recovery after ischemia. J. Biol. Chem. 2018, 293, 3281-3292. [CrossRef] [PubMed]

81. Saenz-Mendez, P.; Kztz, A.; Perez-Kempner, M.L.; Ventura, O.N.; Vazquez, M. Structural insights into human microsomal epoxide hydrolase by combined homology modeling, molecular dynamics simulations, and molecular docking calculations. Proteins Struct. Funct. Genet. 2017, 85, 720-730. [CrossRef]

82. Lee, M.J.; Bhattarai, D.; Yoo, J.; Miller, Z.; Park, J.E.; Lee, S.; Lee, W.; Driscoll, J.J.; Kim, K.B. Development of novel epoxyketonebased proteasome inhibitors as a strategy to overcome cancer resistance to carfilzomib and bortezomib. J. Med. Chem. 2019, 62, 4444-4455. [CrossRef] [PubMed] 